\title{
RESPONSABILIDADE DA ADMINISTRAÇÃO PÚBLICA NA TERCEIRIZAÇÃO DOS SERVIÇOS: ANÁLISE SOBRE O ÔNUS DA PROVA
}

\author{
Daisy Doro Perez \\ Lourival José de Oliveira***
}

SUMÁRIO: Introdução; 2 A Responsabilidade da administração pública na terceirização. Uma retrospectiva jurisprudencial; 3 A indefinição do Supremo Tribunal Federal quanto ao ônus da prova; 4 A quem cabe o ônus da prova?; 5 Os riscos da terceirização desenfreada; 6 Considerações finais; Referências.

RESUMO: O objeto deste artigo é a análise da responsabilidade subsidiária da administração pública pelo inadimplemento das obrigações trabalhistas nos casos de terceirização dos serviços e a questão do ônus da prova da sua culpa. O estudo justifica-se após a decisão do STF no recurso extraordinário n ${ }^{0}$ 760.931-DF e objetiva perquirir a quem incumbe o ônus da prova nesse caso, os possíveis prejuízos aos trabalhadores e os riscos de violação aos princípios constitucionais, decorrentes da terceirização desenfreada. No decorrer do estudo, constatou-se que subsiste a responsabilidade subsidiária, desde que comprovada a culpa da administração, não tendo o STF se posicionado definitivamente acerca do ônus da prova; é dificultoso ao trabalhador produzir a referida prova, justificando-se a inversão do ônus probatório em seu favor; há possibilidade de violação dos princípios da administração pública e risco adicional da precarização da condição dos trabalhadores. Adotou-se o método dedutivo, com pesquisas jurisprudenciais, legislativas e doutrinárias.

PALAVRAS-CHAVE: Administração pública; Ônus da prova; Responsabilidade subsidiária; Terceirização.

\section{RESPONSIBILITY OF THE PUBLIC ADMINISTRATION IN THE OUTSOURCING OF SERVICES: ANALYSIS ON THE BURDEN OF PROOF}

ABSTRACT: The objective of this article is the analysis of the subsidiary responsibility of the public administration for the default of the labor obligations in cases of outsourcing of services and the question of the burden of proof of their fault. The study

\footnotetext{
"Mestra em Direito pela Universidade de Marília - Unimar, Marília, São Paulo, Brasil.

E-mail: daisydoro@gmail.com

** Doutor em Direito das Relações Sociais pela PUCSP. Docente dos Programas de Doutorado/Mestrado da Universidade de Marília; Docente do Curso de Graduação da Universidade Estadual de Londrina, Brasil.
} 
is justified after the decision of the STF in Extraordinary Appeal No. 760.931-DF and aims to investigate who is responsible for the burden of proof in this case, the possible damages to workers and the risks of violation of constitutional principles, resulting from unrestrained outsourcing. In the course of the study, it was found that: subsidiary liability still exists, provided the management's fault is proven, and the STF has not definitively positioned itself on the burden of proof; it is difficult for the worker to produce said proof, justifying the reversal of the burden of proof in his favor; there is a possibility of violation of the principles of public administration and additional risk of the precariousness of the workers' condition. The deductive method was adopted, with jurisprudential, legislative and doctrinal researches.

KEY WORDS: Burden of Proof; Outsourcing; Public Administration; Subsidiary Responsibility.

\section{RESPONSABILIDAD DE LA ADMINISTRACIÓN PÚBLICA EM LA TERCERIZACIÓN DE LOS SERVICIOS: ANÁLISIS SOBRE LA CARGA DE LA PRUEBA}

RESUMEN: El objeto de este artículo es el análisis de la responsabilidad subsidiaria de la administración pública por el incumplimiento de las obligaciones laborales en los casos de tercerización de los servicios y la cuestión de la carga de la prueba de su culpa. El estudio se justifica después de la decisión del STF en el Recurso Extraordinario $\mathrm{n}^{0} 760.931-\mathrm{DF}$ y objetiva examinar a quien incumbe la carga de la prueba en ese caso, los posibles perjuicios a los trabajadores y los riesgos de violación a los principios constitucionales, derivados de la tercerización desenfrenada. En el transcurso del estudio, se constató que: subsiste la responsabilidad subsidiaria, desde que comprobada la culpa de la administración, no teniendo el STF se posicionó definitivamente sobre la carga de la prueba; es difícil para el trabajador producir la referida prueba, justificándose la inversión de la carga probatoria en su favor; hay posibilidad de violación de los principios de la administración pública y riesgo adicional de la precarización de la condición de los trabajadores. Se adoptó el método deductivo, con investigaciones jurisprudenciales, legislativas y doctrinarias.

PALABRAS-CLAVE: Administración Pública; Carga de la Prueba; Responsabilidad Subsidiaria; Tercerización.

\section{INTRODUÇÃO}

Em 30 de março de 2017 foi proferido pelo Supremo Tribunal Federal acórdão no recurso extraordinário $\mathrm{n}^{\mathrm{o}}$ 760.931-DF, fixando tese de repercussão geral no 
sentido de que o inadimplemento dos encargos trabalhistas dos empregados da empresa contratada não transfere automaticamente ao Poder Público contratante a responsabilidade pelo seu pagamento.

Reafirmou-se, na esteira do que já havia sido decidido na ação declaratória de constitucionalidade $\mathrm{n}^{\mathrm{0}} 16-\mathrm{DF}$, a vedação da transferência automática à administração pública dos encargos trabalhistas inadimplidos pela empresa contratada, como consequência do disposto no $\S 1^{\circ}$ do artigo 71 da lei $n^{\circ} 8.666$ de 21 de junho de 1993, o qual fora reconhecido como constitucional na referida ação.

Entretanto, na redação final da tese de repercussão geral, nada se diz a respeito da responsabilização por culpa do ente público e tampouco sobre o ônus da prova nesse caso. Tais questões foram levantadas nos diversos votos proferidos e, principalmente, no debate que precedeu à redação da tese.

Concomitantemente, o instituto da terceirização foi regulamentado pela lei $\mathrm{n}^{\mathrm{o}} 13.429$ de 31 de março de 2017, logo mais alterada pela lei $\mathrm{n}^{0} 13.467$ de 13 de julho de 2017 , permitindo-se a sua ampla utilização, inclusive para consecução das atividades principais do tomador de serviços.

Destarte, justifica-se o presente estudo diante da discussão que se abre a partir da decisão do STF, acerca da subsistência da responsabilização subsidiária da administração pública nos casos de terceirização, bem como a questão relativa ao ônus da prova da sua culpa. É necessário, ainda, perquirir quais os riscos do uso indiscriminado da terceirização nos serviços públicos, no que se refere aos prejuízos que poderão advir aos trabalhadores terceirizados em face da sua dificuldade na produção da prova.

É relevante, ainda, refletir se a terceirização dos serviços no âmbito da administração pública de forma ilimitada poderá violar os princípios constitucionais da administração pública, principalmente os do interesse público e do concurso público.

Sendo, assim, o presente trabalho se propõe a uma análise crítica, com vistas a encontrar respostas para as seguintes indagações:

A decisão do Supremo Tribunal Federal afastou completamente a possibilidade de responsabilização dos órgãos públicos no caso de descumprimento das obrigações trabalhistas por parte das empresas por eles contratadas?

Considerada a possibilidade de responsabilização subsidiária do ente público por culpa, a quem cabe o ônus da prova? 
Após a referida decisão, haverá estímulo ao uso indiscriminado da terceirização dos serviços no âmbito da administração pública? Haverá risco de descumprimento dos princípios constitucionais?

Adotou-se o método dedutivo, com pesquisas jurisprudenciais, legislativas e doutrinárias, construindo-se um contexto crítico a partir da decisão do Supremo Tribunal Federal, com uma análise integral do instituto da terceirização na administração pública.

\section{A RESPONSABILIDADE DA ADMINISTRAÇÃO PÚBLICA NA TERCEIRIZAÇÃO. UMA RETROSPECTIVA JURISPRUDENCIAL}

A questão da responsabilização da administração pública, foi tratada inicialmente através da resolução ${ }^{0} 96$ de 11 de setembro de 2000 do Tribunal Superior do Trabalho (TST), que deu nova redação ao item IV da Súmula no 331 :

O inadimplemento das obrigações trabalhistas, por parte do empregador, implica na responsabilidade subsidiária do tomador dos serviços, quanto àquelas obrigações, inclusive quanto aos órgãos da administração direta, das autarquias, das fundações públicas, das empresas públicas e das sociedades de economia mista, desde que hajam participado da relação processual e constem também do título executivo judicial (art. 71 da Lei $\left.n^{0} 8.666 / 93\right)^{03}$.

Por sua vez, preceitua o artigo 71 da lei no 8.666 de 21 de junho de 1993.

Art. 71. O contratado é responsável pelos encargos trabalhistas, previdenciários, fiscais e comerciais resultantes da execução do contrato.

$\S 10$ A inadimplência do contratado, com referência aos encargos trabalhistas, fiscais e comerciais não transfere à Administração Pública a responsabilidade por seu pagamento, nem poderá onerar o objeto do contrato ou restringir a regularização e o uso das obras e edificações, inclusive perante o Registro de Imóveis.

$[\ldots]$.

${ }^{03}$ Tribunal Superior do Trabalho. Resolução no 96 de 11 setembro de 2010. Diário da Justiça da República Federativa do Brasil. Brasília, 2010. Disponível em: https://hdl.handle.net/20.500.12178/4294. Acesso em: 05 maio 2018. 
A partir de então, fomentou-se uma corrente que defendia a tese de que o TST teria deixado de aplicar o referido dispositivo legal, declarando, ainda que de forma indireta, a sua inconstitucionalidade. Nessa linha, foi proposta a Ação Declaratória de Constitucionalidade $(\mathrm{ADC}) \mathrm{n}^{\mathrm{0}} 16$ - DF visando à declaração de constitucionalidade do artigo citado. A pretensão foi julgada procedente e o Supremo Tribunal Federal declarou a sua constitucionalidade, não impedindo, porém, a responsabilização subsidiária da administração pública ${ }^{04}$.

A ementa da decisão, proferida em 24 de novembro de 2010, é a seguinte:

RESPONSABILIDADE CONTRATUAL. Subsidiária. Contrato com a administração pública. Inadimplência negocial do outro contraente. Transferência consequente e automática dos seus encargos trabalhistas, fiscais e comerciais, resultantes da execução do contrato, à administração. Impossibilidade jurídica. Consequência proibida pelo art. $71, \S 1^{\circ}$, da Lei federal $\mathrm{n}^{\mathrm{o}}$ 8.666/93. Constitucionalidade reconhecida dessa norma. Ação direta de constitucionalidade julgada, nesse sentido, procedente. Voto vencido. É constitucional a norma inscrita no art. $71, \S 1^{\circ}$ da Lei federal $n^{\circ} 8.666$, de 26 de junho de 1993 , com a redação dada pela Lei $n^{0} 9.032$ de $1995^{05}$.

Para adequar-se à referida decisão, através da tesolução no 174 de 24 de maio de 2011, o TST deu nova redação ao item IV e inseriu um item V na Súmula $n^{0}$ 331, os quais ficaram assim redigidos:

IV - O inadimplemento das obrigações trabalhistas, por parte do empregador, implica a responsabilidade subsidiária do tomador dos serviços, quanto àquelas obrigações, desde que haja participado da relação processual e conste também do título executivo judicial.

V - Os entes integrantes da Administração Pública direta e indireta respondem subsidiariamente, nas mesmas condições do item IV, caso evidenciada a sua conduta culposa no cum-

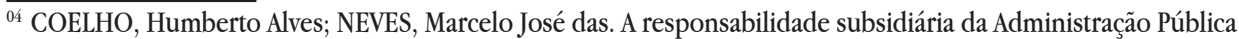
na terceirização, segundo a jurisdição constitucional: obrigações, encargo probatório e limites interpretativos - um contributo prático aos potenciais sujeitos do processo: trabalhador, empresa terceirizada, administração pública e órgão jurisdicional. Revista LTr, São Paulo, v. 81, n. 05, p. 577-590, maio 2017, p. 579.

${ }^{05}$ Supremo Tribunal Federal. Ação Declaratória de Constitucionalidade $n^{\circ} 16$ Distrito Federal. Relator: Ministro Cezar Peluso. Brasília, 09 set. 2011. Diário de Justiça Eletrônico. Disponível em: http://redir.stf.jus.br/paginadorpub/paginador.jsp?docTP $=$ AC\&docID $=627165$. Acesso em: 02 maio 2018.
} 
primento das obrigações da Lei $n^{0} 8.666$, de 21.06.1993, especialmente na fiscalização do cumprimento das obrigações contratuais e legais da prestadora de serviço como empregadora. A aludida responsabilidade não decorre de mero inadimplemento das obrigações trabalhistas assumidas pela empresa regularmente contratada $a^{06}$.

Entretanto, o julgamento proferido na $\mathrm{ADC} \mathrm{n}^{0}$ 16-DF não pacificou as disputas que estavam surgindo na esfera dos processos trabalhistas, mas as acirrou, multiplicando o número de Reclamações Constitucionais e Recursos Extraordinários perante o Supremo Tribunal Federal, arguindo afronta à decisão proferida naquela ADC. Sendo assim, reconhecendo a repercussão geral do tema (Tema no 246), foi eleito como paradigma o Recurso Extraordinário (RE) no 760931-DF. Trata-se de recurso interposto pela União Federal contra decisão proferida pela Justiça do Trabalho, que lhe impôs a responsabilidade subsidiária pelas verbas trabalhistas devidas pela empresa contratada, como decorrência da sua culpa in vigilando. A União sustentou que a decisão violava o texto constitucional, especialmente os artigos $5^{\circ}$, inciso II, 37, caput, 97 e 102, $\S 2^{\circ}$ e, ainda, desobedecia ao que fora decidido na ADC $\mathrm{n}^{\mathrm{0}} 16-\mathrm{DF}$.

Ao final, o recurso foi parcialmente conhecido e julgado procedente, transcrevendo-se, abaixo, parcialmente, a sua ementa:

EMENTA: RECURSO EXTRAORDINÁRIO REPRESENTATIVO DE CONTROVÉRSIA COM REPERCUSSÃO GERAL. DIREITO CONSTITUCIONAL. DIREITO DO TRABALHO. TERCEIRIZAÇÃO NO ÂMBITO DA ADMINISTRAÇÃO PÚBLICA. SÚMULA 331, IV E V, DO TST. CONSTITUCIONALIDADE DO ART. 71, § $1^{\circ}$, DA LEI No 8.666/93. TERCEIRIZAÇÃO COMO MECANISMO ESSENCIAL PARA A PRESERVAÇÃO DE POSTOS DE TRABALHO E ATENDIMENTO DAS DEMANDAS DOS CIDADÃOS. HISTÓRICO CIENTÍFICO. LITERATURA: ECONOMIA E ADMINISTRAÇÃO. INEXISTÊNCIA DE PRECARIZAÇÃO DO TRABALHO HUMANO. RESPEITO ÀS ESCOLHAS LEGÍTIMAS DO LEGISLADOR. PRECEDENTE: ADC 16. EFEITOS VINCULANTES. RECURSO PARCIALMENTE CONHECIDO E PROVIDO. FIXAÇÃO DE TESE PARA APLICAÇÃO EM CASOS SEMELHANTES.

${ }^{06}$ Tribunal Superior do Trabalho. Resolução n ${ }^{0} 174$ de 24 maio 2011. Diário Eletrônico da Justiça do Trabalho. Brasília, 2011. Disponível em: https:/hdl.handle.net/20.500.12178/13179. Acesso em: 05 maio 2018. 


\section{$[\ldots]$}

9. Recurso Extraordinário parcialmente conhecido e, na parte admitida, julgado procedente para fixar a seguinte tese para casos semelhantes: "O inadimplemento dos encargos trabalhistas dos empregados do contratado não transfere automaticamente ao Poder Público contratante a responsabilidade pelo seu pagamento, seja em caráter solidário ou subsidiário, nos termos do art. $71, \S 1^{\circ}$, da Lei $n^{0} 8.666 / 93^{\prime 07}$.

Em 03 de abril de 2018, em julgamento proferido pela Sétima Turma do Tribunal Superior do Trabalho (TST), no processo n ${ }^{\circ}$ TST-RR-20261-74.2015.5.04.0017, foi dado provimento ao Recurso de Revista impetrado pelo Departamento de Trânsito do Rio Grande do Sul - DETRAN/RS para excluir a sua responsabilidade subsidiária pelos créditos trabalhistas inadimplidos pela empresa prestadora de serviços por ele contratada, sob o fundamento de que, com a decisão proferida no Recurso Extraordinário no $n^{0}$ 760.931-DF, a condenação da administração pública só é admissível quando houver prova inequívoca da conduta omissiva ou comissiva do ente público na fiscalização dos contratos. No caso concreto, concluiu a Turma que não fora evidenciada por parte do reclamante a conduta culposa na fiscalização do contrato ${ }^{08}$.

Conclui-se, assim, que não ficou afastada completamente a hipótese de responsabilização subsidiária da administração pública pelos encargos trabalhistas devidos pela empresa terceirizada, desde que haja prova da sua conduta omissiva ou comissiva. No julgamento do $\mathrm{RE} \mathrm{n}^{\mathrm{0}} 760.931$, no debate em plenário realizado para votação da tese de repercussão geral, percebe-se a intenção dos julgadores em manter a possibilidade de responsabilização da administração pública, pela inclusão da expressão automaticamente, com o intuito de deixar a porta aberta para a discussão da configuração da culpa.

Até o momento mantém-se inalterada a redação do item V da Súmula ${ }^{\circ} 331$ do TST. A recente decisão proferida pela Sétima Turma do TST aponta no sentido de que, após o pronunciamento do Supremo Tribunal Federal, o ônus da prova da

\footnotetext{
${ }^{07}$ Supremo Tribunal Federal. Recurso Extraordinário n ${ }^{0}$ 760.931-DF. Relatora: Ministra Rosa Weber. Brasília, 12 set. 2017. Diário de Justiça Eletrônico. Disponível em: http://www.stf.jus.br/portal/processo/verProcessoAndamento.asp? numero $=760931 \&$ classe $=\mathrm{RE} \&$ origem $=\mathrm{AP} \&$ recurso $=0 \&$ tipoJulgamento $=\mathrm{M}$. Acesso em: 02 maio 2018 .

${ }^{08}$ Tribunal Superior do Trabalho. Recurso de Revista. Processo $\mathrm{n}^{\mathrm{o}}$ TST-RR-20261-74.2015.5.04.0017. $7^{\mathrm{a}}$ Turma. Relator: Altino Pedrozo dos Santos. Brasília, 06 de abr. 2018. Diário de Justiça Eletrônico. Disponível em: http://aplicacao4.tst.jus.br/consultaProcessual/resumoForm.do?consulta=1\&numeroInt $=315526 \&$ anoInt $=2017$. Acesso em: 02 maio 2018.
} 
culpa da administração pública é do trabalhador. É o que se pretende investigar no tópico a seguir.

\section{A INDEFINIÇÃO DO SUPREMO TRIBUNAL FEDERAL QUANTO AO ÔNUS DA PROVA}

Examinando-se o inteiro teor do acórdão proferido no RE $n^{0}$ 760.931-DF, colhem-se os diversos posicionamentos manifestados quanto ao ônus da prova ao longo das várias sessões.

A ministra relatora, Rosa Weber, assim se pronunciou na conclusão de seu voto:

Assim, não adimplidas, pela prestadora de serviços, as obrigações trabalhistas devidas aos seus empregados, caberia à Administração Pública, tomadora dos serviços, demonstrar, conforme lhe competia, que se desincumbira dos deveres impostos pela legislação, quanto ao acompanhamento e fiscalização da execução do contrato, a fim de afastar sua culpa in vigilando. Concluir pela irresponsabilidade estatal ou pela imposição do encargo probatório ao trabalhador, em hipóteses como a debatida, implicaria desconsideração do valor social do trabalho e dos princípios trabalhistas, que visam a assegurar o resguardo dos direitos fundamentais do trabalhador e do princípio da dignidade humana, em homenagem à nova ordem constitucional ${ }^{09}$.

O ministro Edson Fachin também negando provimento ao recurso, assim se manifestou em seu voto:

Por fim, no que respeita ao ônus da prova, não há dúvida de que compete ao Poder Público o ônus de demonstrar que realizou fiscalização adequada e de que tomou as medidas indicadas para buscar sanar eventuais irregularidades trabalhistas, sob pena de configuração de culpa in vigilando. Não é razoável atribuir ao cidadão prova de fato negativo, ou seja,

\footnotetext{
${ }^{09}$ Supremo Tribunal Federal. Recurso Extraordinário n ${ }^{0}$ 760.931-DF. Relatora: Ministra Rosa Weber. Brasília, 12 set. 2017. Diário de Justiça Eletrônico. Disponível em: http://www.stf.jus.br/portal/processo/verProcessoAndamento.asp? numero $=760931 \&$ classe $=$ RE\&origem $=A P \&$ recurso $=0 \&$ tipoJulgamento $=\mathrm{M}$. Acesso em: 02 maio 2018.
} 
prova de não fiscalização. Esse tipo de exigência é ainda mais absurdo no caso dos trabalhadores, diante da sua manifesta hipossuficiência, ao passo que se trata de prova de considerável simplicidade para o Poder Público ${ }^{10}$.

Acompanhando a tese da ministra Rosa Weber, afirmou o ministro Luís Roberto Barroso:

[..] E estou propondo, Presidente, acrescentar as seguintes conclusões à tese a ser firmada - que seria a terceira, considerando as duas primeiras da Ministra Rosa: compete à Administração Pública o ônus de provar que houve fiscalização. Portanto, não é o empregado que tem que fazer a prova negativa de que não houve; a Administração é que tem que provar que ela fiscalizou $[\ldots]^{11}$.

O ministro Luís Fux, abrindo a divergência, deu provimento ao recurso, negando a existência de responsabilidade subsidiária da administração pública, expressando entendimento de que houve omissão eloquente por parte do legislador para não criar a responsabilidade subsidiária. ${ }^{12}$

Os ministros Ricardo Lewandowski e Celso de Mello acompanharam o voto da relatora ${ }^{13}$.

O ministro Marco Aurélio manifestou-se claramente no sentido de que, uma vez que o artigo 71 da lei $n^{0} 8.666$ de 21 de junho de 1993 afastou a responsabilidade da administração pública, também a desincumbiu de provar que fiscalizou a empresa contratada:

Não tenho como, Presidente, hígido o artigo 71 da Lei ${ }^{0}$ $8.666 / 1993^{14}$, no que afasta a responsabilidade da Administração Pública, partir para o que tenho como extravagante e

\footnotetext{
${ }^{10}$ Supremo Tribunal Federal. Recurso Extraordinário no 760.931-DF. Relatora: Ministra Rosa Weber. Brasília, 12 set. 2017. Diário de Justiça Eletrônico. Disponível em: http://www.stf.jus.br/portal/processo/verProcessoAndamento.asp?numero $=760931 \&$ classe $=$ RE\&origem $=A P \&$ recurso $=0 \&$ tipoJulgamento $=M$. Acesso em: 02 maio 2018.

${ }^{11}$ Idem.

${ }^{12}$ Ibidem.

${ }^{13}$ Ibidem.

${ }^{14}$ Supremo Tribunal Federal. Recurso Extraordinário n ${ }^{0}$ 760.931-DF. Relatora: Ministra Rosa Weber. Brasília, 12 set. 2017. Diário de Justiça Eletrônico. Disponível em: http://www.stf.jus.br/portal/processo/verProcessoAndamento.asp?numero $=760931 \&$ classe $=\mathrm{RE} \&$ origem $=\mathrm{AP} \&$ recurso $=0 \&$ tipoJulgamento $=\mathrm{M}$. Acesso em: 02 maio 2018.
} 
assentar, apesar da presunção decorrente desse artigo, de não haver responsabilidade, incumbir à contratante a prova.

O ministro Dias Toffoli alinhou-se aos votos proferidos pelos ministros Luiz Fux e Marco Aurélio. No entanto, no último debate ocorrido para votação da tese de repercussão geral, embora votando favoravelmente à tese, afirmou que entendia que o ônus da prova caberia à administração pública. Retificando o seu voto, o ministro Gilmar Mendes acompanha os referidos ministros ${ }^{15}$.

Do voto da ministra Cármen Lúcia, que também deu provimento ao recurso, extrai-se o seguinte trecho no que se refere à prova:

A alegada ausência de comprovação, em juízo, pela União, da efetiva fiscalização do contrato administrativo não substitui a necessidade de "prova taxativa no nexo de causalidade entre a conduta da Administração e o dano sofrido pelo trabalhador". $[\ldots]^{16}$.

Por fim, do voto do ministro Alexandre de Moraes, destaca-se o seguinte trecho:

[...] O que pode induzir à responsabilização do Poder Público é a comprovação de um comportamento sistematicamente negligente em relação aos terceirizados; ou seja, a necessidade de prova do nexo de causalidade entre a conduta comissiva ou omissiva do Poder Público e o dano sofrido pelo trabalhador. Se não houver essa fixação expressa, clara e taxativa por esta Corte, estaremos possibilitando, novamente, outras interpretações que acabem por afastar o entendimento definitivo sobre a responsabilização da Administração Pública nas terceirizações, com a possibilidade de novas condenações do Estado por mero inadimplemento e, consequentemente a manutenção do desrespeito à decisão desta Corte na $\mathrm{ADC} 16[\ldots]^{17}$.

\footnotetext{
${ }^{15}$ Supremo Tribunal Federal. Recurso Extraordinário no 760.931-DF. Relatora: Ministra Rosa Weber. Brasília, 12 set. 2017. Diário de Justiça Eletrônico. Disponível em: http://www.stf.jus.br/portal/processo/verProcessoAndamento.asp? numero $=760931 \&$ classe $=\mathrm{RE} \&$ origem $=\mathrm{AP} \&$ recurso $=0 \&$ tipoJulgamento $=\mathrm{M}$. Acesso em: 02 maio 2018.

${ }^{16}$ Ibidem.

${ }^{17}$ Ibidem.
} 
Da leitura do inteiro teor do acórdão, principalmente dos debates, fica evidenciada uma percepção por parte dos ministros de que a Justiça do Trabalho, embora tenha dado nova redação à Súmula $n^{0} 331$, acrescentando-lhe o item V, havia encontrado um meio de contornar o que fora decidido na $\mathrm{ADC} \mathrm{n}^{0} 16-\mathrm{DF}$, pela aplicação de um critério de culpa presumida da administração, prescindindo de uma prova concreta. E que tal comportamento passou a gerar um acúmulo de reclamações e recursos extraordinários ao Supremo Tribunal Federal.

Em vários trechos do acórdão e, principalmente, no debate em que se procedeu a fixação da tese de repercussão geral, percebe-se que a preocupação principal foi reafirmar o que fora decidido na $\mathrm{ADC} \mathrm{n}^{0} 16-\mathrm{DF}$, especialmente, quanto à necessidade de existir prova cabal da conduta omissiva ou comissiva do Poder Público e que tal conduta tenha nexo de causalidade com os danos sofridos pelo trabalhador. A inexistência da referida prova ou a presunção de culpa da administração pela alegação genérica de ausência do cumprimento do seu dever de fiscalização é que vinha motivando inúmeras reclamações junto ao Supremo Tribunal Federal por descumprimento da referida ADC. Assim, para evitar a proliferação de recursos e reclamações com o mesmo tema, o Supremo Tribunal Federal frisou a necessidade da existência de prova, sem se manifestar de maneira taxativa a quem incumbe o ônus dessa prova e nem de que forma a parte se desincumbirá do mesmo, deixando a questão para ser apreciada nas instâncias trabalhistas.

Portanto, conclui-se que o Supremo Tribunal Federal quis reafirmar o que fora decidido na $\mathrm{ADC} \mathrm{n}^{0} 16$, deixando, agora, mais explícita a necessidade de existir no processo prova de culpa da administração, não bastando, para sua condenação subsidiária que o juiz se baseie apenas em presunção genérica de culpa. Tanto assim é que, na redação e votação da tese, os ministros optaram por não se referir à culpa e nem tampouco ao ônus da prova.

Uma vez que a definição do onus probandi permanece na órbita de competência dos juízes trabalhistas, passa-se, então, a perquirir de quem é o ônus da prova.

\section{A QUEM CABE O ÔNUS DA PROVA?}

A regra geral para atribuição do ônus da prova no processo do trabalho, muito semelhante àquela contida no artigo 373 do Código de Processo Civil, encontra-se no artigo 818 da Consolidação das Leis do Trabalho. 
Art. 818. O ônus da prova incumbe:

I - ao reclamante, quanto ao fato constitutivo de seu direito;

II - ao reclamado, quanto à existência de fato impeditivo, modificativo ou extintivo do direito do reclamante.

$\S 1$ o Nos casos previstos em lei ou diante de peculiaridades da causa relacionadas à impossibilidade ou à excessiva dificuldade de cumprir o encargo nos termos deste artigo ou à maior facilidade de obtenção da prova do fato contrário, poderá o juízo atribuir o ônus da prova de modo diverso, desde que o faça por decisão fundamentada, caso em que deverá dar à parte a oportunidade de se desincumbir do ônus que lhe foi atribuído.

$[\ldots]$

Assim, incumbe a cada parte, com base no princípio do interesse, alegar e provar aquilo que pretende seja sopesado pelo julgador. Oportuno trazer o ensinamento de Cândido Rangel Dinamarco, baseado na doutrina de Giuseppe Chiovenda.

[...] A síntese dessas disposições consiste na regra de que o ônus da prova incumbe à parte que tiver interesse no conhecimento do fato a ser provado (Chiovenda), ou seja, àquela que se beneficie desse reconhecimento; essa fórmula coloca adequadamente o tema do onus probandi no quadro do interesse como mola propulsora da efetiva participação dos litigantes, segundo o empenho de cada um em obter a vitória. $[\ldots]^{18}$.

As disposições gerais que tratam do ônus da prova podem ser compreendidas de forma dupla: primeiramente como regra dirigida às partes no sentido de nortear o seu comportamento no processo acerca da produção da prova referente às suas alegações. Segundo, como regra dirigida ao magistrado para permitir a ele, no momento do julgamento, verificar em que medida as partes se desincumbiram dos seus respectivos ônus probatórios, quando ainda não tenha se convencido acerca de fatos relevantes para o proferimento da decisão, de forma a impedir o non liquet ${ }^{19}$.

A atribuição do ônus da prova feita pelo legislador é prévia e estática, no

${ }^{18}$ DINAMARCO, Cândido Rangel. Instituições de Direito Processual Civil. Vol. III. 1. ed. São Paulo: Malheiros, 2001, p. $72-73$, grifo do autor.

${ }_{19}$ BUENO, Cassio Scarpinella. Manual de Direito Processual Civil. 2. ed. São Paulo: Saraiva, 2016, p. 350. 
sentido de que é invariável em relação às peculiaridades da causa, enquanto que a atribuição feita pelo juiz é considerada dinâmica, porque é feita à luz de uma situação concreta ${ }^{20}$.

No caso do reclamante que ingressa com uma ação trabalhista contra a empresa terceirizada, sua empregadora e, concomitantemente contra o órgão público tomador dos serviços, poder-se-ia afirmar, considerando apenas a estática do ônus da prova, que seria dele o encargo de provar o nexo causal entre a conduta culposa do referido órgão e o inadimplemento das obrigações trabalhistas por parte do seu empregador. Tal fato, seria, a princípio, constitutivo do seu direito em ver responsabilizada subsidiariamente a administração pública contratante numa eventual condenação do seu empregador.

Porém, há que se considerar as peculiaridades da terceirização ocorrida nos serviços públicos, cujo processo de contratação e deveres das partes contratantes encontra-se disciplinado na lei $n^{\circ} 8.666$ de 21 de junho de 1993.

Primeiramente, cabe ressaltar que a administração pública tem a prerrogativa de fiscalizar a execução do contrato administrativo de prestação de serviços, bem como de aplicar sanções ao contratado no caso da sua inexecução total ou parcial, conforme disposto no artigo 58, incisos III e IV da referida lei. Além disso, de acordo com o artigo 67, tem o dever de acompanhar e fiscalizar a execução do contrato por um representante especialmente designado.

As condutas inerentes a esse dever encontram-se detalhadas na Instrução Normativa $\mathrm{n}^{0} 5$ de 26 de maio de 2017, do Ministério do Planejamento, Desenvolvimento e Gestão ${ }^{21}$, que dispõe sobre as regras e diretrizes do procedimento de contratação de serviços sob o regime de execução indireta no âmbito da administração pública federal direta, autárquica e fundacional. Estabeleceu-se um padrão fiscalizatório a ser seguido pelo administrador público e demais servidores incumbidos da fiscalização do contrato.

Considerando que no caso da administração pública, a terceirização que importa, aquela que via de regra enseja a formulação de pedido de responsabilidade subsidiária, é a contratação de serviços de natureza contínua com dedicação exclusiva

\footnotetext{
${ }^{20}$ DIDIER JR., Fredie; BRAGA, Paula Sarno; OLIVEIRA, Rafael Alexandria de. Curso de Direito Processual Civil. Vol. 2. 12. ed. Salvador: Jus Podivm, 2017, p. 123.

${ }^{21}$ Ministério do Planejamento, Desenvolvimento e Gestão. Instrução Normativa ${ }^{0} 5$ de 26 de maio de 2017. Diário Oficial [da] República Federativa do Brasil, Brasília, DF, 2017. Disponível em: https://www.comprasgovernamentais.gov.br/index.php/legislacao/instrucoes-normativas/760-instrucao-normativa-n-05-de-25-de-maio-de-2017. Acesso em: 11 maio 2018.
} 
de mão de obra ${ }^{22}$, passa-se a destacar da Instrução Normativa $\mathrm{n}^{\mathrm{o}} 05$ referida acima os dispositivos que interessam ao tema sob enfoque.

A fiscalização administrativa do contrato consiste no acompanhamento dos aspectos administrativos da execução dos serviços quanto às obrigações previdenciárias, fiscais e trabalhistas, bem como quanto às providências tempestivas nos casos de inadimplemento (artigo 40, inciso III).

No anexo VIII-B da já mencionada Instrução Normativa, fica explicitado como deve ser realizada, na prática, a fiscalização do cumprimento das obrigações trabalhistas e sociais. O órgão contratante deverá exigir os documentos que comprovem o cumprimento de todas as obrigações trabalhistas, desde o momento da contratação do empregado até a extinção do contrato, sendo que o descumprimento de tais obrigações pode dar ensejo à rescisão do contrato de prestação de serviços pela administração pública.

Analisando-se o inteiro teor da citada Instrução Normativa, evidencia-se que o dever de fiscalização do cumprimento das obrigações trabalhistas relativas aos empregados terceirizados não está sujeito à discricionariedade, devendo o órgão público praticar os atos administrativos específicos nela previstos, os quais devem ser registrados e documentados por servidores públicos, formalmente designados para os misteres de gestão e fiscalização (artigo 42).

Embora tenha sido voto vencido, oportuno trazer trecho do voto da ministra Rosa Weber ${ }^{23}$, acerca do ônus da prova:

É inequivocamente desproporcional impor aos terceirizados o dever probatório quanto ao descumprimento da aludida fiscalização por parte da Administração Pública.

Reforça, por fim, a compreensão quanto ao dever probatório da Administração Pública, em situações como a debatida, a técnica processual da distribuição dinâmica do ônus da prova, a qual, fundamentada nos princípios da igualdade, aptidão para a prova e cooperação, surge em contraposição ao ônus estático da prova (art. 818 da CLT e art. 333 do já revogado

${ }^{22}$ COELHO, Humberto Alves; NEVES, Marcelo José das. A responsabilidade subsidiária da Administração Pública na terceirização, segundo a jurisdição constitucional: obrigações, encargo probatório e limites interpretativos - um contributo prático aos potenciais sujeitos do processo: trabalhador, empresa terceirizada, administração pública e órgão jurisdicional. Revista LTr, São Paulo, v. 81, n. 05, maio 2017, p. 584.

${ }^{23}$ Supremo Tribunal Federal. Recurso Extraordinário no 760.931-DF. Relatora: Ministra Rosa Weber. Brasília, 12 set. 2017, grifos no original. Diário de Justiça Eletrônico. Disponível em: http://www.stf.jus.br/portal/processo/ verProcessoAndamento.asp? numero $=760931 \&$ classe $=$ RE\&origem $=$ AP\&recurso $=0 \&$ tipoJulgamento $=\mathrm{M}$. Acesso em: 02 maio 2018. 
CPC de 1973) e tem por diretriz a efetiva capacidade probatória de cada parte, antídoto para a chamada "prova diabólica". Decorre, tal técnica, do caráter publicista da jurisdição e da necessidade de equilíbrio na relação processual, entre outros.

A doutrina conceitua a prova diabólica como aquela cuja produção é considerada impossível ou muito difícil. Distinguindo a prova unilateralmente diabólica:

Pode ser, no entanto, que a prova seja insuscetível de ser produzida por aquele que deveria fazê-lo, de acordo com a lei, mas apta a ser realizada pelo outro. Nessa hipótese, caso as próprias partes não tenham convencionado validamente a distribuição do ônus da prova de modo diverso ao estabelecido pelo legislador, poderá o juiz distribuí-lo dinamicamente, caso a caso, na fase de saneamento ou instrutória - em tempo de o onerado dele desincumbir-se [...].

É o caso da prova unilateralmente diabólica, isto é, impossível (ou extremamente difícil) para uma das partes, mas viável para a outra ${ }^{24}$.

O artigo 818 da Consolidação das Leis do Trabalho, já transcrito alhures, prevê a possibilidade de o juiz atribuir o ônus da prova de modo diverso, nos casos previstos em lei ou diante de peculiaridades da causa relacionadas à impossibilidade ou à excessiva dificuldade de cumprir o encargo ou à maior facilidade de obtenção da prova do fato contrário.

Ao comentar o $\S 1^{\circ}$ do artigo 373 do Código de Processo Civil, cuja redação é praticamente idêntica ao $\S 1^{\circ}$ do artigo 818 da CLT, Artur César de Souza afirma que

As circunstâncias da causa que justificam a possibilidade de o juiz distribuir diversamente o ônus da prova são mais abrangentes que a inversão do ônus da prova prevista no Código de Defesa do Consumidor, pois podem decorrer não apenas de circunstâncias de hipossuficiência, mas também de qualquer outra questão de natureza social, econômica ou mesmo cultural que possa ensejar a impossibilidade ou a excessiva dificuldade de cumprir o encargo nos termos do art. 373 ou à

${ }^{24}$ DIDIER JR., Fredie; BRAGA, Paula Sarno e OLIVEIRA, Rafael Alexandria de. Curso de Direito Processual Civil. Volume 2. 12. ed. Salvador: Jus Podivm, 2017, p. 132, grifos do autor. 
maior facilidade de obtenção da prova do fato contrário.

$[\ldots]$

Esse dispositivo faz com que o juiz observe no processo as diferenças sociais, econômicas e culturais das partes, a fim de que, diante dessas diferenças e dificuldades dela resultantes, determine ele juiz a inversão do ônus da prova ${ }^{25}$.

No caso do empregado terceirizado que ingressa com ação contra o seu empregador e contra o órgão público contratante, além da sua evidente condição de hipossuficiência como trabalhador, ressalta a sua diferença social e econômica em relação aos outros demandados, o que justificaria plenamente a redistribuição dinâmica do ônus da prova.

Atribuir ao trabalhador o encargo de provar a conduta culposa da administração pública, decorrente da não fiscalização do cumprimento das obrigações trabalhistas no curso do contrato de trabalho, enquadra-se na hipótese legal de impossibilidade ou excessiva dificuldade de cumprir o encargo.

Uma vez que a administração tem o dever legal de fiscalização, cujo procedimento está previsto na norma regulamentar destacada acima, é muito mais fácil que ela prove que cumpriu os atos administrativos ali descritos, trazendo ao processo as provas documentais e testemunhais que corroborem a sua atuação diligente e efetiva no sentido de evitar o descumprimento das obrigações trabalhistas pela empresa contratada. Só assim é que se poderá admitir que ela seja eximida da sua responsabilidade subsidiária.

Ademais, o processo judicial é regido pelo princípio constitucional da isonomia, devendo o juiz assegurar às partes igualdade de tratamento. $\mathrm{O}$ princípio liga-se, de um lado, à ideia de que o juiz deve atuar de modo imparcial em relação às partes e de outro, à ideia de paridade de armas. O dever do juiz de tratar as partes com paridade não significa que ele deve agir passivamente diante da desigualdade material existente entre as partes. $O$ direito de ser tratado de forma isonômica compreende, também, o direito de ver reconhecida a diferença ${ }^{26}$.

É evidente a desigualdade existente entre o empregado terceirizado e a administração pública no que se refere à possibilidade de produzir prova da culpa

\footnotetext{
${ }^{25}$ SOUZA, Artur César de. Código de Processo Civil. Anotado, comentado e interpretado. Vol. II. São Paulo: Almedina, 2015, p. 318-319, grifos do autor.

${ }^{26}$ MEDINA, José Miguel Garcia. Curso de Direito Processual Civil Moderno. 4. ed. São Paulo: Revista dos Tribunais, 2018, p. 125-126.
} 
desta última, pois ao empregado terceirizado é praticamente impossível fazê-la enquanto que ao órgão público ela será fácil, desde que efetivamente tenha cumprido o seu dever legal de fiscalização. O raciocínio contrário resultaria numa grande disparidade de armas entre as partes. Sendo assim, incumbe ao juiz, no exercício da direção do processo, corrigir essa situação e recolocar o trabalhador numa situação de igualdade com as outras partes processuais, invertendo o ônus da prova.

A decisão do Supremo Tribunal Federal no RE no $760.931 / \mathrm{DF}$ reafirmou a necessidade de prova cabal da existência de culpa da administração pública, não podendo a mesma ser responsabilizada automaticamente pelo inadimplemento das obrigações trabalhistas por parte da empresa terceirizada, com base em presunção de culpa. Por certo, caberá ao reclamante alegar em sua inicial não somente o inadimplemento das obrigações trabalhistas pelo seu empregador, mas também que tal inadimplência decorreu da conduta culposa do ente público tomador dos serviços, consistente em não fiscalizar adequadamente, durante a vigência do contrato e no seu término, o cumprimento das obrigações trabalhistas.

Caberá ao juiz, diante das peculiaridades da terceirização nos serviços públicos, determinar a inversão do ônus da prova e apreciar, na decisão de mérito, se a administração pública dele se desincumbiu satisfatoriamente. Atribuir esse ônus ao reclamante equivaleria, na prática, à impossibilidade de responsabilização subsidiária da administração pública pelo inadimplemento das obrigações trabalhistas.

\section{OS RISCOS DA TERCEIRIZAÇÃO DESENFREADA}

A possibilidade de terceirização dos serviços estatais foi aberta com o decreto-lei n ${ }^{\circ} 200$ de 25 de fevereiro de 1967, que no seu artigo 10 prevê que as atividades da administração federal devem ser amplamente descentralizadas, com o objetivo de impedir o crescimento desmesurado da máquina administrativa, recorrendo sempre que possível à execução indireta, mediante contrato com a inciativa privada. A terceirização no serviço público encontra-se ainda respaldada pela própria lei ${ }^{0} 8666$ de 21 de junho de 1993 e pelo Enunciado n 331 do Tribunal Superior do Trabalho.

No decreto $\mathrm{n}^{0} 2.271$ de 7 de julho de 1997 , que dispõe sobre a contratação de serviços pela Administração Pública Federal, traçaram-se parâmetros sobre as atividades que podem ou não ser terceirizadas, sendo o mesmo substituído pelo decreto $\mathrm{n}^{0} 9.507$ de 21 de setembro de 2018. Entretanto, tais limites não impediram 
o crescimento desenfreado da terceirização no serviço público, à medida que, na reforma do Estado, houve uma reestruturação nas carreiras e a extinção de cargos públicos. Além disso, outras duas leis incentivaram a terceirização da atividade-fim no serviço público, quais sejam, a lei ${ }^{0} 9.637$ de 15 de maio de 1998, que permite a subcontratação através das denominadas organizações sociais e a Lei de Responsabilidade Fiscal (lei complementar $\mathrm{n}^{0} 101$ de 4 de maio de 2000), cujo objetivo é reduzir as despesas com o funcionalismo público, inibindo, assim, a realização de concursos públicos e incentivando a terceirização, uma vez que as despesas com subcontratação de empresas, contratação temporária, emergencial e de comissionados não são computadas como despesas de pessoal27 .

Some-se, ainda, como incentivo à terceirização, a mitigação da responsabilidade da administração pública, prevista no $\S 1^{\circ}$ do artigo 71 da lei no 8.666 de 21 de junho de 1993, reconhecido como constitucional na $\mathrm{ADC} \mathrm{n}^{0} 16-\mathrm{DF}$, reafirmada mais recentemente no julgamento do $\mathrm{RE} \mathrm{n}^{\mathrm{o}}$ 760.931-DF.

$\mathrm{O}$ discurso que tenta justificar a ampla utilização da terceirização nos serviços públicos argumenta que tal prática permite à administração pública dar cumprimento ao princípio da eficiência. Nesse sentido, os itens 2 e 6 da ementa do acórdão proferido no já citado RE $n^{0} 760.931-\mathrm{DF}^{28}$ :

2. A cisão de atividades entre pessoas jurídicas distintas não revela qualquer intuito fraudulento, consubstanciando estratégia, garantida pelos artigos $1^{\circ}$, IV, e 170 da Constituição brasileira, de configuração das empresas, incorporada à Administração Pública por imperativo de eficiência (art. 37, caput, CRFB), para fazer frente às exigências dos consumidores e cidadãos em geral, justamente porque a perda de eficiência representa ameaça à sobrevivência da empresa e ao emprego dos trabalhadores.

6. A Administração Pública, pautada pelo dever de eficiência (art. 37, caput, da Constituição), deve empregar as soluções

${ }^{27}$ DRUCK, Graça; SENA, Jeovana; PINTO, Marina Morena; ARAÚJO, Sâmia. A terceirização no serviço público: particularidades e implicações. In: CAMPOS, A. G. (org.). Terceirização do Trabalho no Brasil: novas e distintas perspectivas para o debate. Brasília: Ipea, 2018, p. 118-119. Disponível em http://www.ipea. gov.br/portal/index.php?option $=$ com_content\&view $=$ article\&id $=32326$ :terceirizacao-do-trabalho-no-brasil-novas-e-distintas-perspectivas-para-o-debate\&catid $=410: 2018 \&$ directory $=1$. Acesso em: 11 maio 2018 .

${ }^{28}$ Supremo Tribunal Federal. Recurso Extraordinário n ${ }^{0}$ 760.931-DF. Relatora: Ministra Rosa Weber. Brasília, 12 set. 2017. Diário de Justiça Eletrônico. Disponível em: http://www.stf.jus.br/portal/processo/verProcessoAndamento.asp? numero $=760931 \&$ classe $=$ RE\&origem $=$ AP\&recurso $=0 \&$ tipoJulgamento $=M$. Acesso em: 02 maio 2018. 
de mercado adequadas à prestação de serviços de excelência à população com os recursos disponíveis, mormente quando demonstrado, pela teoria e pela prática internacional, que a terceirização não importa precarização às condições dos trabalhadores.

Entretanto, em se tratando de serviços públicos, não se pode partir da premissa de que a terceirização significa eficiência. Primeiramente, porque diferentemente da iniciativa privada, o objetivo da atuação da administração pública não é obter lucro e nem tampouco conquistar um mercado consumidor. Seu objetivo consiste em satisfazer o interesse público, promovendo o bem comum. Uma atuação administrativa eficiente é aquela que presta serviços de qualidade, com racionalidade para otimizar os recursos disponíveis e, principalmente, sem o desperdício de recursos públicos, mormente por meio da corrupção.

Além disso, a justificativa da eficiência não pode se constituir numa brecha para que seja contornada a regra da obrigatoriedade do concurso público, prevista no artigo 37, inciso II, da Constituição Federal, o que, naturalmente, viria a contrariar o princípio da moralidade, previsto no caput do mesmo artigo. Ademais, a execução dos serviços públicos, por servidores selecionados mediante concurso público, atende ao princípio da impessoalidade e à igualdade de acesso aos cargos e empregos públicos a todos os brasileiros, o que não ocorre num processo de terceirização, em que os empregados são selecionados pela empresa contratada. Tal processo pode ser utilizado para viabilizar interesses escusos dos administradores públicos, consistindo a terceirização num meio para contratação de apadrinhados, contribuindo para a ineficiência e o aparelhamento do Estado.

O que se tem presenciado nas últimas décadas é um processo de verdadeiro desmonte do serviço público, nas três esferas administrativas, com a redução do quadro de pessoal permanente e o sucateamento das estruturas físicas, sempre justificado pelo discurso neoliberal da necessidade de redução de despesas e do tamanho do Estado. Por outro lado, proliferam os cargos comissionados, nem sempre preenchidos por critérios de competência e probidade, mas por mera indicação política. Nesse sentido,

Nos anos 1970, esse padrão de desenvolvimento e o Estado social entraram em crise, e o capital buscou se reestruturar no 
plano mundial, redefinindo-se o papel e o tipo de Estado. Era o início da chamada era neoliberal, cuja evolução desigual e combinada até os dias atuais foi marcada por privatizações de empresas públicas e pelo enxugamento da máquina do Estado, com a redução das políticas públicas universais e com uma forte ideologia norteadora das reformas do Estado - inclusive no Brasil -, que sustentava a necessidade de introduzir no serviço público o modelo gerencial do setor privado ${ }^{29}$.

Nesse contexto, surge a terceirização como uma pretensa solução para dar eficiência na prestação dos serviços públicos. Entretanto, a sua utilização de forma desenfreada pode servir para o atendimento de interesses privados em detrimento do interesse público. Advertindo sobre esses riscos,

Por meio da terceirização, o capital se organiza estrategicamente em todos os vieses da máquina estatal na defesa dos interesses de mercado, em privilégio de camadas empresariais muito restritas da sociedade, acentuando o ambiente propício à promiscuidade entre o público e o privado, e aprofundando o caráter patrimonialista das relações entre os governos e as elites econômicas. O corporativismo das elites burocráticas, de servidores públicos privilegiados, firmemente combatido pela Reforma do Aparelho de Estado, acaba substituído pelo corporativismo das empresas empreiteiras, prestadoras de serviços, não menos agressivo na colonização privada do espaço estatal $^{30}$.

Os riscos se tornam ainda mais evidentes, quando se busca mitigar cada vez mais a reponsabilidade subsidiária do Estado, sob o falso argumento de que o interesse particular, no caso o do trabalhador terceirizado, não pode prevalecer sobre o interesse público, qual seja o do ente público contratante. Estimula-se, assim, um relaxamento por parte dos administradores públicos no cumprimento do seu dever

${ }^{29}$ DRUCK, Graça; SENA, Jeovana; PINTO, Marina Morena; ARAÚJO, Sâmia. A terceirização no serviço público: particularidades e implicações. In: CAMPOS, A. G. (org.). Terceirização do Trabalho no Brasil: novas e distintas perspectivas para o debate. Brasília: Ipea, 2018, p. 117. Disponível em http://www.ipea. gov.br/portal/index.php?option $=$ com_content\&view $=$ article\&id $=32326$ :terceirizacao-do-trabalho-no-brasil-novas-e-distintas-perspectivas-para-o-debate\&catid $=410: 2018 \&$ directory $=1$. Acesso em: 11 maio 2018.

${ }^{30}$ AMORIM, Helder Santos, 2009, p. 76 apud SILVA, Patrícia Pinheiro. Terceirização nos serviços públicos. Revista do TST, Brasília, v. 77, n. 1, jan./mar. 2011, p. 107. Disponível em: https://juslaboris.tst.jus.br/handle/20.500.12178/21256. Acesso em: 02 maio 2018. 
de fiscalização sobre a empresa contratada, a qual por sua vez, se sentirá pouco motivada ao cumprimento rigoroso das suas obrigações trabalhistas. Sobre o assunto, assim se manifestou Tereza Aparecida Asta Gemignani:

A responsabilização subsidiária do Estado visa preservar o interesse público sobre interesses outros, nem sempre confessáveis, daqueles que participam de um processo licitatório apresentando propostas fictícias, já contando com futura inadimplência de certas obrigações. Trata-se de cumprir o princípio da legalidade e fazer valer a finalidade do ordenamento jurídico, evitando que a licitação seja usada para auferir vantagens e burlar a legislação trabalhista pelo contratante, causando pesado ônus para a sociedade como um todo, que arcará com os custos da máquina judiciária a ser movimentada pelos trabalhadores para o recebimento de seus direitos, além dos prejuízos causados pela falta de recolhimento das contribuições devidas ${ }^{31}$.

Tampouco se pode afirmar que a terceirização não implica a precarização da condição dos trabalhadores. Não sendo o escopo deste trabalho um aprofundamento sobre o tema da precarização, citam-se a esse respeito dois respeitados estudiosos do assunto.

Em síntese, a terceirização é o fio condutor da precarização do trabalho no Brasil, e se constitui num fenômeno onipresente em todos os campos e dimensões do trabalho, pois é uma prática de gestão/organização/controle que discrimina, ao mesmo tempo em que é uma forma de contrato flexível e sem proteção trabalhista, é também sinônimo de risco de saúde e de vida, responsável pela fragmentação das identidades coletivas dos trabalhadores, com a intensificação da alienação e da desvalorização humana do trabalhador, assim como é um instrumento de pulverização da organização sindical, que incentiva a concorrência entre os trabalhadores e seus sindicatos, e ainda a terceirização põe um "manto de invisibilidade" dos trabalhadores na sua condição social, como facilitadora do descumprimento da legislação trabalhista, como forma ideal para o

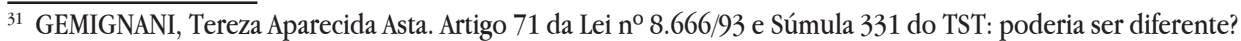
Revista do TST, Brasília, v. 77, n. 1, jan./mar. 2011, p. 45. Disponível em: https:/juslaboris.tst.jus.br/handle/20.500.12178/21256. Acesso em: 02 maio 2018. 
empresariado não ter limites (regulados pelo Estado) no uso da força de trabalho e da sua exploração como mercadoria ${ }^{32}$.

Ao longo do tempo foram se ampliando os permissivos legais para utilização da terceirização nos serviços públicos, ao mesmo tempo que, por meio do $\S 1^{\circ}$ do artigo 71 da lei no 8.666 de 21 de junho de 1993, limitou-se a responsabilidade da administração pública pelo inadimplemento das obrigações trabalhistas. Sustentar o entendimento de que cabe ao empregado terceirizado provar a culpa do órgão público na fiscalização do contrato de prestação de serviços implicará, na prática, quase que a sua completa irresponsabilidade, conforme discorrido no item anterior. Nesse cenário, estimula-se o uso indevido da terceirização no âmbito público, com o risco de desvirtuar a finalidade do instituto, resultando na ineficiência na prestação dos serviços públicos, com o risco adicional de precarização das condições de trabalho dos empregados terceirizados.

\section{CONSIDERAÇÕES FINAIS}

A definição da responsabilização da administração pública na terceirização dos serviços tem como ponto de partida o artigo 71 da lei $\mathrm{n}^{0} 8.666$ de 21 de junho de 1993, o qual veda a transferência da responsabilidade ao órgão contratante dos encargos trabalhistas inadimplidos pelo contratado. O Tribunal Superior do Trabalho, tratando do tema na Súmula de ${ }^{0} 331$, afirmou a possibilidade de responsabilização subsidiária diante da evidência de conduta culposa da administração pública. A controvérsia judicial aprofundou-se diante de decisões da Justiça do Trabalho que condenavam subsidiariamente o órgão público contratante, baseadas em alegações de culpa presumida.

Buscando refrear a proliferação de recursos, o Supremo Tribunal Federal reconheceu a repercussão geral do tema e elegeu como paradigma o RE $n^{0} 760.931$ DF. Diante das manifestações externadas pelos ministros nos debates e nos votos e, também, da posição explicitada em julgamento proferido em recurso de revista pelo TST com base na decisão do STF, concluiu-se que não ficou afastada completamente a hipótese de responsabilização subsidiária da administração pública pelos encargos trabalhistas no caso do seu inadimplemento pela empresa terceirizada contratada.

32 ANTUNES, Ricardo; DRUCK, Graça. A terceirização como regra? Revista do TST, Brasília, v. 79, n. 4, out./dez. 2013, p. 224. Disponível em: https:/hdl.handle.net/20.500.12178/55930. Acesso em: 11 maio 2018. 
No julgamento do referido RE, foi reafirmada pelo STF a necessidade de existência de prova cabal da conduta omissiva ou comissiva do órgão público, para possibilitar a sua condenação subsidiária. Ressaltou-se que a condenação não deve se basear em presunção de culpa ou em alegações genéricas de ausência do cumprimento do dever de fiscalização. Examinando-se o teor dos votos e as manifestações em plenário, concluiu-se que a questão do ônus da prova e sua valoração não foi definida pelo STF, permanecendo na órbita de apreciação das instâncias trabalhistas.

Pacificado pelo Supremo Tribunal Federal o entendimento de que é necessária a existência no processo de prova concreta da culpa da administração pública, a decisão condenatória não poderá basear-se tão somente em alegação genérica de descumprimento do dever de fiscalização.

A atribuição desse ônus, no caso da terceirização dos serviços públicos, deve considerar as suas particularidades, uma vez que cabe à administração pública o dever legal de fiscalizar a execução dos contratos, inclusive o cumprimento das obrigações trabalhistas. O padrão fiscalizatório está especificado em normas regulamentares, não havendo margem à discricionariedade. Portanto, é muito mais fácil para o órgão público produzir a prova do cumprimento dos seus deveres e, assim, eximir-se da sua responsabilidade subsidiária.

Por outro lado, a produção da prova de conduta culposa da administração por parte do empregado reclamante enquadra-se na hipótese legal de impossibilidade ou excessiva dificuldade, configurando a denominada prova diabólica, justificando-se, assim, a inversão do ônus da prova nesse caso.

A terceirização dos serviços públicos surge e ganha corpo num contexto marcado por diversas reformas que objetivaram reduzir o tamanho do Estado. Não atende necessariamente ao princípio da eficiência, podendo consistir numa brecha para burlar a regra da obrigatoriedade de contratação de pessoal por meio de concurso público. A terceirização desenfreada não atende ao interesse público, podendo, inclusive, servir a interesses privados.

Nas últimas décadas foram se ampliando os permissivos legais para utilização da terceirização nos serviços públicos, ao mesmo tempo em que se limitou a possibilidade de responsabilização da administração pública pelo inadimplemento das obrigações trabalhistas, a qual é meramente subsidiária. Sustentar o entendimento de que cabe ao empregado terceirizado o ônus de provar a culpa do ente 
público implicará, pela extrema dificuldade no seu cumprimento, a completa irresponsabilidade da administração pública. Nesse cenário, estimula-se o uso indevido da terceirização, com o risco de desvirtuar a finalidade do instituto, resultando na ineficiência na prestação dos serviços públicos, e o risco adicional de precarização das condições de trabalho dos empregados terceirizados.

\section{REFERÊNCIAS}

ANTUNES, Ricardo; DRUCK, Graça. A terceirização como regra? Revista do TST, Brasília, v. 79, n. 4, p. 214-231, out./dez. 2013. Disponível em: https:/hdl.handle. net/20.500.12178/55930. Acesso em: 11 maio 2018.

BRASIL. Constituição da República Federativa do Brasil, de 05 de outubro de 1988. Diário Oficial [da] República Federativa do Brasil, Brasília, DF, 5 out. 1988. Disponível em: http://www.planalto.gov.br/ccivil_03/Constituicao/Constituicao. htm. Acesso em: 05 maio 2018.

BRASIL. Decreto no 2.271 de 07 de julho de 1997. Diário Oficial [da] República Federativa do Brasil, Brasília, DF, 8 jul. 1997. Disponível em: http://www.planalto. gov.br/ccivil_03/decreto/d2271.htm. Acesso em: 05 maio 2018.

BRASIL. Decreto no 9.507 de 21 de setembro de 2018. Diário Oficial [da] República Federativa do Brasil, Brasília, DF, 24 set. 2018. Disponível em: http://www. planalto.gov.br/ccivil_03/_ato2015-2018/2018/decreto/D9507.htm. Acesso em: 30 set. 2018.

BRASIL. Decreto-Lei no 200 de 25 de fevereiro de 1967. Diário Oficial [da] República Federativa do Brasil, Brasília, DF, 27 mar. 1967. Disponível em: http://www. planalto.gov.br/ccivil_03/decreto-lei/Del0200.htm. Acesso em: 05 maio 2018.

BRASIL. Decreto-Lei n ${ }^{0} 5.452$, de $1^{\circ}$ de maio de 1943. Consolidação das Leis do Trabalho. Diário Oficial [da] República Federativa do Brasil, Rio de Janeiro, RJ, 9 ago. 1943. Disponível em: http://www.planalto.gov.br/ccivil_03/decreto-lei/ Del5452.htm. Acesso em: 05 maio 2018.

BRASIL. Lei no 8.666 de 21 de junho de 1993. Diário Oficial [da] República Fe- 
derativa do Brasil, Brasília, DF, 22 jun. 1993. Disponível em: http://www.planalto.gov.br/ccivil_03/leis/18666cons.htm. Acesso em: 05 maio 2018.

BRASIL. Lei no 9.637 de 15 de maio de 1998. Diário Oficial [da] República Federativa do Brasil, Brasília, DF, 18 maio 1998. Disponível em: http://www.planalto. gov.br/ccivil_03/leis/19637.htm. Acesso em: 05 maio 2018.

BRASIL. Lei no 13.105 , de 16 de março de 2015. Código de Processo Civil. Diário Oficial [da] República Federativa do Brasil, Brasília, DF, 17 mar. 2015. Disponível em: http://www.planalto.gov.br/ccivil_03/_ato2015-2018/2015/lei/113105.htm. Acesso em: 05 maio 2018.

BRASIL. Lei no 13.429 de 31 de março de 2017. Diário Oficial [da] República Federativa do Brasil, Brasília, DF, 31 mar. 2017. Disponível em: http://www.planalto. gov.br/ccivil_03/_ato2015-2018/2017/lei/13429.htm. Acesso em: 05 maio 2018.

BRASIL. Lei no 13.467 de 13 de julho de 2017. Diário Oficial [da] República Federativa do Brasil, Brasília, DF, 14 jul. 2017. Disponível em: http://www.planalto. gov.br/ccivil_03/_ato2015-2018/2017/lei/13467.htm. Acesso em: 05 maio 2018.

BRASIL. Lei Complementar $\mathrm{n}^{0} 101$ de 4 de maio de 2000. Diário Oficial da [da] República Federativa do Brasil, Brasília, DF, 5 maio 2000. Disponível em: http:// www.planalto.gov.br/ccivil_03/leis/lcp/lcp101.htm. Acesso em: 05 maio 2018.

BRASIL. Ministério do Planejamento, Desenvolvimento e Gestão. Instrução Normativa $\mathrm{n}^{\circ} 5$ de 26 de maio de 2017. Diário Oficial [da] República Federativa do Brasil, Brasília, DF, 2017. Disponível em: https://www.comprasgovernamentais. gov.br/index.php/legislacao/instrucoes-normativas/760-instrucao-normativa-n-05-de-25-de-maio-de-2017. Acesso em: 11 maio 2018.

BRASIL. Supremo Tribunal Federal. Ação Declaratória de Constitucionalidade $\mathrm{n}^{\mathrm{o}}$ 16 Distrito Federal. Relator: Ministro Cezar Peluso. Brasília, 09 set. 2011. Diário de Justiça Eletrônico. Disponível em: http://redir.stf.jus.br/paginadorpub/paginador. jsp?docTP $=$ AC\&docID =627165. Acesso em: 02 maio 2018.

BRASIL. Supremo Tribunal Federal. Recurso Extraordinário no 760.931-DF. Relatora: Ministra Rosa Weber. Brasília, 12 set. 2017. Diário de Justiça Eletrônico. Disponível em: http://www.stf.jus.br/portal/processo/verProcessoAndamento.as- 
p? numero $=760931 \&$ classe $=$ RE $\&$ origem $=A P \&$ recurso $=0 \&$ tipoJulgamento $=M$. Acesso em: 02 maio 2018.

BRASIL. Tribunal Superior do Trabalho. Recurso de Revista. Processo ${ }^{0}$ TST-RR-20261-74.2015.5.04.0017. $7^{\mathrm{a}}$ Turma. Relator: Altino Pedrozo dos Santos. Brasília, 06 de abr. 2018. Diário de Justiça Eletrônico. Disponível em: http:// aplicaca04.tst.jus.br/consultaProcessual/resumoForm.do?consulta $=1 \&$ numeroIn$\mathrm{t}=315526$ \&anoInt $=2017$. Acesso em: 02 maio 2018.

BRASIL. Tribunal Superior do Trabalho. Resolução no 96 de 11 setembro de 2010. Diário da Justiça da República Federativa do Brasil. Brasília, 2010. Disponível em: https:/hdl.handle.net/20.500.12178/4294. Acesso em: 05 maio 2018.

BRASIL. Tribunal Superior do Trabalho. Resolução $n^{\circ} 174$ de 24 maio 2011. Diário Eletrônico da Justiça do Trabalho. Brasília, 2011. Disponível em: https:/hdl.handle.net/20.500.12178/13179. Acesso em: 05 maio 2018.

BRASIL. Tribunal Superior do Trabalho. Súmula no 331. Disponível em: http:// www3.tst.jus.br/jurisprudencia/Sumulas_com_indice/Sumulas_Ind_301_350.html. Acesso em: 05 maio 2018.

BUENO, Cassio Scarpinella. Manual de Direito Processual Civil. 2. ed. São Paulo: Saraiva, 2016.

COELHO, Humberto Alves; NEVES, Marcelo José das. A responsabilidade subsidiária da Administração Pública na terceirização, segundo a jurisdição constitucional: obrigações, encargo probatório e limites interpretativos - um contributo prático aos potenciais sujeitos do processo: trabalhador, empresa terceirizada, administração pública e órgão jurisdicional. Revista LTr, São Paulo, v. 81, n. 05, p. 577-590, maio 2017.

DIDIER JR., Fredie; BRAGA, Paula Sarno; OLIVEIRA, Rafael Alexandria de. Curso de Direito Processual Civil. Vol. 2. 12. ed. Salvador: Jus Podivm, 2017.

DINAMARCO, Cândido Rangel. Instituições de Direito Processual Civil. Vol. III. São Paulo: Malheiros, 2001.

DRUCK, Graça; SENA, Jeovana; PINTO, Marina Morena; ARAÚJO, Sâmia. A terceiri- 
zação no serviço público: particularidades e implicações. In: CAMPOS, A. G. (org.). Terceirização do Trabalho no Brasil: novas e distintas perspectivas para o debate. Brasília: Ipea, 2018, p. 113-141. Disponível em: http://www.ipea.gov.br/portal/ index.php?option =com_content\&view $=$ article $\&$ id $=32326$ :terceirizacao-do-trabalho-no-brasil-novas-e-distintas-perspectivas-para-o-debate $\&$ catid $=410: 2018 \&$ directory $=1$. Acesso em: 11 maio 2018.

GEMIGNANI, Tereza Aparecida Asta. Artigo 71 da Lei no $8.666 / 93$ e Súmula 331 do TST: poderia ser diferente? Revista do TST, Brasília, v. 77, n. 1, p. 32-53, jan./mar. 2011. Disponível em: https:/juslaboris.tst.jus.br/handle/20.500.12178/21256. Acesso em: 02 maio 2018.

MEDINA, José Miguel Garcia. Curso de Direito Processual Civil Moderno. 4. ed. São Paulo: Revista dos Tribunais, 2018.

SILVA, Patrícia Pinheiro. Terceirização nos serviços públicos. Revista do TST, Brasília, v. 77, n. 1, p. 95-130, jan./mar. 2011. Disponível em: https:/juslaboris.tst.jus.br/ handle/20.500.12178/21256. Acesso em: 02 maio 2018.

SOUZA, Artur César de. Código de Processo Civil: Anotado, comentado e interpretado. Vol. II. São Paulo: Almedina, 2015.

Recebido em: 06/10/2018 